\title{
The Identification of Mangrove Ecosystem Services for Decision Making
}

\author{
Suharno ${ }^{1 *}$,Emmy Saraswati ${ }^{2}$ \\ ${ }^{1}$ Economics and Development Studies, Faculty of Economics and Business, Jenderal Soedirman \\ University \\ ${ }^{2}$ Economics and Development Studies, Faculty of Economics and Business, Jenderal Soedirman \\ University
}

\begin{abstract}
Directly or indirectly, goods and services available in natural ecosystems will contribute to human welfare. The human ability to calculate the economic value of ecosystem goods and services is an important thing to do for integrated environmental decision making, sustainable business practices, and land use planning with its geographical scale, and the level of local-social wisdom. For this reason, a comprehensive review and study are needed by analyzing mangrove ecosystem services. Discussions with in-depth descriptive methods are applied to evaluate mangrove ecosystem services specifically, and focus methods and techniques are used for data analysis, and further to understand their potential and disadvantages.
\end{abstract}

\section{Introduction}

Mangroves are intertidal ecosystems that are located along tropical and subtropical coasts. Mangrove swamps supply food needs for ecosystems such as sediment traps with various nutrients absorbed and prevent erosion on shorelines (Jusoff, 2013). Mangrove forests also supply various types of raw materials, such as food, fuelwood, wood, and tannins (De Groot et al. 2002). It is noted, among others, the types of fish, shrimp, and crabs using mangrove ecosystems as ground nurseries and feeding ground (Robertson \& Duke, 1987; Beck et al. 2001). Unfortunately, the indication of global data records mangrove forests has dropped dramatically (Giri et al. 2008). Observation findings from 1980, had a $25 \%$ decline in mangrove forests (FAO 2007). The main contributors are a land conversion for shrimp ponds, illegal logging, freshwater pollution, and utilization (Barbier et al. 2011).

As part of the Segara Anakan estuary ecosystem and the largest mangrove forest area, the mangrove forest in Segara Anakan Lagoon, Cilacap Regency once triumphed in Java in the past. The area of mangroves in the Segara Anakan area reaches 21,500 ha (Sasaki \& Sunarto 1994). Note that in various periods, several studies reported that environmental stress in the Segara Anakan mangrove forest continued. The situation with various pressures reduced mangrove forest in 2013 with the remaining land area of 6,716 ha (Purwanto et al. 2014). The process of ongoing development that continues to increase such

* Corresponding author: suharno@unsoed.ac.id 
as settlements, industries, rice fields, fish ponds causes the conversion of mangrove areas that have surpassed regenerative ability to live mangroves (Sukarjo, 2016). Continued efforts to pressure human activities have caused an increase in land surface with mangrove status being critical. For this reason, an assessment of the critical status of the mangrove forest is needed. How to measure the critical indicators of land for mangroves can be done by assessing the density of mangroves with the vegetation index. Calculation of the vegetation index of this model is done by utilizing remote sensing technology (Adam et al. 2010). The vegetation index is very important because it can be used as an indicator in biomass estimation (Foody, 2003), estimated leaf area index (Kovacs et al. 2004) and estimation of primary productivity (Komiyama et al. 2008). Patterns of leaf spectral characteristics can distinguish radiation intensity from reflected electromagnetic power (Jusoff, 2006).

Mangrove forests are the main ecosystems that support life that is important in coastal and marine areas. Every ecosystem has a benefit value, both direct and indirect benefits in the form of ecosystem services. Ecosystem services are ecological processes or ecosystem components that have the potential to provide a flow of benefits to the community. The Millennium Ecosystem Assessment (2005) classifies ecosystem services in four main categories, namely provisioning services, regulating services, and cultural services. Therefore, to realize sustainable development with the concept of Ecosystem-Based Management and ecosystem services in Cilacap District especially in Kampung Laut Subdistrict, it is necessary to analyze mangrove ecosystem services in some coastal areas of Kampung Laut District so that the government and the community can know the benefits or services owned by the mangrove forest so that the forest can continue to be preserved and used as a fortress in disaster risk reduction, especially coastal disasters and can be a reference in disaster management for regions with similar characteristics. The purpose of this study was to analyze the services of mangrove ecosystems in the mangrove area of Ujung Alang Village, Kampung Laut District, and calculate the value of mangrove ecosystem services.

\section{Analytical method}

The data collected is divided into two types, namely primary data and secondary data. Primary data includes all results of interviews and direct observations in the field. Secondary data in the form of data collected from the results of literature studies, literature review, and institutional data.

Identifying ecosystem services is based on the Millennium Ecosystem Assessment (2005), where identification is divided into three services, namely provider services, regulatory services, and cultural services. Assessment of ecosystem services in Ujung Alang Village uses a short approach to economic valuation by calculating the total economic value of mangrove ecosystem services. The assessment is based on the value of each activity identified in ecosystem services.

Analysis of research data was carried out using descriptive analysis techniques. Descriptive analysis is used to describe the results of the calculation of mangrove ecosystem services.

\section{Results and discussions}

Segara Anakan Lagoon is a national strategic area in accordance with Indonesian government regulation no 26/2008. The total area of the Segara Anakan lagoon and its environmental area is 24,968 ha (Ludwig 1984). The lagoon region has coordinates of $7^{\circ}$ 
$37 ' 22$ "-7 ${ }^{\circ} 47^{\prime} 37 "$ south latitude and $108^{\circ} 45^{\prime} 11$ "-109 ${ }^{\circ} 2 ' 54 "$ east longitude. Segara Anakan Lagoon has three rivers that supply high sediment, namely; Citanduy River, Cibeureum River, and Cikonde River, which have an impact on increasing the expansion of the characteristics of mangroves in Segara Anakan Lagoon and its surroundings. This condition is in accordance with the opinion of Setyawan (2010) which states that geologically, the Segara Anakan lagoon area tends to decrease due to sedimentation and mangrove expansion.

The opening of rice fields encouraged the decline of the Segara Anakan mangrove area. The opening of rice fields has happened for quite a long time and still continues to this day. In addition, until now there is still found illegal logging due to market demand, wood products from mangrove logging can be used as firewood for cooking needs, and home pillar materials. Illegal logging has reduced the diversity of mangrove species (Yuwono et al. 2007) although outreach efforts on the importance of preserving mangrove ecosystems by government activists and conservation have always been made to inhibit illegal logging. Changes in land use from Segara Anakan and the decline in mangrove areas can be seen in Figure 1.

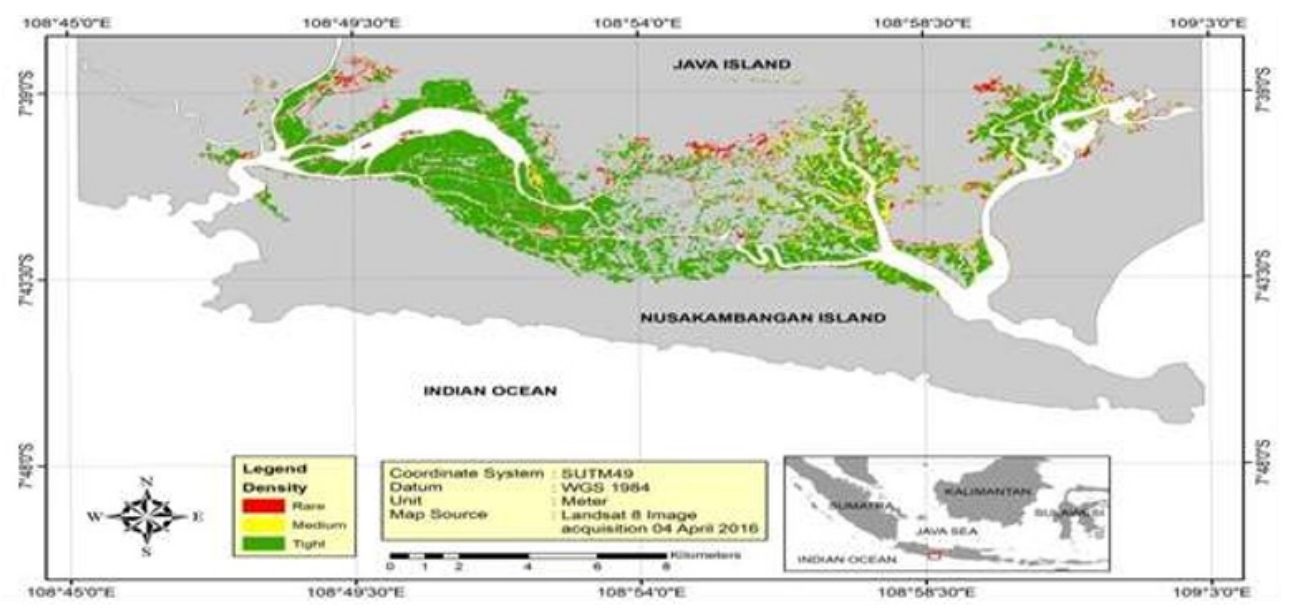

Fig 1. Segara Anakan Land Mangrove Area

The identification of mangrove ecosystem services aims to facilitate the grouping of benefits provided by the ecosystem.

1. Provider / Production Services

Provider/production services are services/benefits provided by mangrove ecosystems in the form of goods and services. The resulting activities are in the form of food providers for the surrounding community in the form of tothok fish, shrimp, crab, and shellfish producers. Data from BPS (2017), the people of Ujung Alang Village are predominantly working as fishermen so that not many people use mangrove forests to meet their daily food needs.

The Department of Environment, Water, Heritage, and the Arts (2009) explained that provider services do not always talk about the use of organisms living in an ecosystem. In addition to utilizing organisms that live in the mangrove ecosystem, the utilization of parts of mangrove trees can also be categorized in the activities of the service provider. However, based on the results of interviews, processing of parts of mangrove trees such as stems, leaves, and seeds is in the experimental stage so that the processed products cannot be commercialized. 
Table 1. Summary of Services and Activities

\begin{tabular}{|c|c|}
\hline Types of Services & Example Activities \\
\hline Provider / Production Services & a. Food providers (fish, shrimp, crabs, and tothok shells) \\
\hline Regulatory / Regulatory Services & $\begin{array}{c}\text { a. Benefits of agriculture } \\
\text { b. Protective ponds from coastal erosion } \\
\text { c. Provider of biodiversity } \\
\text { d. Carbon producer }\end{array}$ \\
\hline Cultural Services & a. Provision of tourism opportunities \\
\hline
\end{tabular}

2. Regulatory or regulatory services

The second service is regulatory or regulatory services found in Ujung Alang village. Regulatory/regulatory services are the result of the ability of ecosystems to regulate climate, water cycles and biochemistry, land surface processes, and various biological processes (Department of Environment, Water, Heritage, and the Arts, 2009). The form of activity from regulatory services or regulators in Ujung Alang village is in the form of activities of ponds, providers of biodiversity, and carbon producers.

Providers of biodiversity can be seen from the research conducted by Sari et al. (2016). Based on the research, there are several types of coastal plants that can be found in Ujung Alang Village. Regulatory services or regulation of the mangrove ecosystem, one of which is a carbon producer. However, the services of mangrove ecosystems in regulating carbon in this study were not examined in more detail because of limited data.

3. Cultural services

Cultural services are services related to benefits that humans get through entertainment, the development of reasoning, relaxation, and spiritual reflection (La Notte et al., 2017). Cultural services can also be said as a bonus that comes along with public awareness of the sustainability of an ecosystem. Based on observations in the field, tourism opportunity service providers are only found in Ujung Alang Village. Utilization of tourism by the people of Ujung Alang Village began to be active in 2010. Based on the results of interviews with tourism managers, Ujung Alang Mangrove tourism began with the creation of a mangrove ecosystem restoration in 2001, which until now continues to grow. The growth of mangrove ecosystem tourism in Ujung Alang Village is also followed by the emergence of new jobs that can improve the economy of surrounding communities such as lodging houses, warungs, sales of mangrove seedlings, etc.

\section{Value of ecosystem services}

Assessment of ecosystem services aims to determine how important an ecosystem is. The greater the value obtained from the ecosystem, the more important an ecosystem is for the sustainability of the surrounding community. Products produced by an ecosystem have different values according to people's needs. Assessment of ecosystem services is carried out using an economic valuation approach. Economic valuation is one method of valuing a resource with an economic approach (De Groot, 2006).

1. Value of fishery provider/production services

The mangrove ecosystem as a food provider means that the ecosystem becomes a producer of food sources for the surrounding community. The value of ecosystem services as food providers is derived from the purchase price or market price of fish, shrimp, and crabs. These products were chosen because they are the dominant products that are usually sought 
after by the surrounding community both as daily food items or for sale. The value of service providers from the mangrove ecosystem is presented in Table 1.

Tabel 2. Fisheries Services

\begin{tabular}{|c|c|c|}
\hline Commodities & Price (Rp) & $\begin{array}{c}\text { Estimated Value of Direct } \\
\text { Benefits (Rp) }\end{array}$ \\
\hline Fish & $8,000-15,000$ & $150,345,590,321$ \\
\hline Tiger shrimp & $50,000-70,000$ & $668,584,049,585$ \\
\hline Shrimp krosok & $8,000-20,000$ & $58,985,980$ \\
\hline Mangrove Crab & $25,000-55,000$ & $24,950,578,987$ \\
\hline \multicolumn{2}{|c|}{ Jumlah } & $912,866,199,880$ \\
\hline
\end{tabular}

2. Value of Regulatory Services or Regulations

Erosion and siltation are one of the major threats to people living in lagoon areas. Erosion can cause damage to the lagoon ecosystem, but silting for some people is used as riceproducing agricultural land. Awareness is needed to maintain the mangrove ecosystem in Kampung Laut Subdistrict, one of the pictures of the adaptation of coastal communities in Kampung Laut District to erosion and siltation that occur. Based on the results of interviews and field identification, the regulating services owned by the mangrove ecosystem in Kampung Laut District are divided into three benefits. The three benefits include agricultural production, protection of ponds from coastal erosion, and maintaining biodiversity.

a. Value of agricultural benefits

The total area of agricultural land in Kampung Laut District is an area of 979 hectares. With sedimentation in the Segara Anakan lagoon, which tends to increase agricultural area (Reichel et al., 2009). Then it can be seen the estimated total value of direct agricultural benefits of Rp. 1,455,786,980 per year.

b. The protective value of ponds from coastal erosion

Pond cultivation in Kampung Laut Subdistrict is polyculture or more decreasing. As explained from one commodity cultivated in one pond area where the selected commodity is mutually beneficial and does not interfere with the growth and development of each commodity. Aquaculture is dominated by two villages in Kampung Laut Subdistrict, namely Klaces Village and Ujung Alang Village. Aquaculture is concentrated in Bondan. Traditional system cultivators have land for cultivation ranging from 0.5 to 5 ha depending on the capital of each farmer.

c. Value of biodiversity

Biodiversity is all living things on earth (plants, animals, and microorganisms) including the genetic diversity they contain and the diversity of ecosystems they form (Kusmana, 2015). Biodiversity values are obtained from calculations that refer to the Ruitenbeek (1992) biodiversity value study, which is the US \$ 15 ha/year, which is then applied to each study area. Adjustment to the study area begins with compound values so that the calculations can be close to accurate. The value of direct benefits from the utilization of mangrove resources for firewood with a total benefit of Rp. 3,768,889,760 per year.

3. Value of cultural services

The cultural services of the mangrove ecosystem that are developing in some sub-districts of Kampung Laut are tourism activities. Cultural service valuation methods can use measurements using tourist travel costs or use the income from tourism activities. The 
cultural service assessment at Ujung Alang uses an approach to income from ongoing tourism activities. Such tourism activities include withdrawal of boat rentals, sales of mangrove seedlings, and the results of rental of residents' houses around tourist attractions. Assessment of cultural services through tourism activities shows that these activities can increase income for villagers. Based on the calculation of cultural service values, the value of cultural services in Ujung Alang is estimated at Rp. 107,920,000 / year.

\section{Conclusion and Implications}

Based on the results of this research, it can be concluded several things regarding the analysis of mangrove ecosystem services. Types of the utilization of Segara waters resources Puppies carried out by the community are the utilization of fisheries, agriculture, and utilization of mangrove wood as fuel. Whereas the total direct benefit value for these activities is Rp. 918,198,786,620 per year. This value illustrates the considerable economic benefits of the Segara Anakan water resources. However, the high sedimentation problem in Segara Anakan can threaten the sustainability of utilization in these waters.

Policies to overcome problems due to the sedimentation process require a systematic action by adhering to ecological principles. The solution to the sedimentation problem must be carried out from upstream to downstream because without a comprehensive solution it can disrupt all the activities in Laguna.

\section{Bibliography}

[1] E. Adam, O. Mutanga, and D. Rugege, Wetl. Ecol. Manag. 18, 281 (2010)

[2] E. B. Barbier, S. D. Hacker, C. Kennedy, E. W. Koch, A. C. Stier, and B. R. Silliman, Ecol. Monogr. 81, 169 (2011)

[3] M. W. Beck, K. L. Heck, K. W. Able, D. L. Childers, D. B. Eggleston, B. M. Gillanders, B. Halpern, C. G. Hays, K. Hoshino, and T. J. Minello, Bioscience 51, 633 (2001)

[4] R. de Groot, Landsc. Urban Plan. 75, 175 (2006)

[5] R. S. de Groot, M. A. Wilson, and R. M. J. Boumans, Ecol. Econ. 41, 393 (2002)

[6] Department of the Environment, Water, Heritage, Ecosystem Services: Key Concepts and Applications, Occasional Paper No 1. (Canberra: Department of the Environment, Water, Heritage, and the Arts, 2009)

[7] G. M. Foody, Int. J. Remote Sens. 24, 4035 (2003)

[8] C. Giri, Z. Zhu, L. L. Tieszen, A. Singh, S. Gillette, and J. A. Kelmelis, J. Biogeogr. 35, 519 (2008)

[9] Ismail, Sulistiono, S. Hariyadi, and H. Madduppa, AACL Bioflux (2018)

[10] K. Jusoff, J. Sustain. Sci. Manag. 1, 27 (2006)

[11] K. Jusoff, Polish J. Environ. Stud. (2013)

[12] A. Komiyama, J. E. Ong, and S. Poungparn, Aquat. Bot. 89, 128 (2008)

[13] J. M. Kovacs, F. Flores-Verdugo, J. Wang, and L. P. Aspden, Aquat. Bot. 80, 13 (2004)

[14] La Notte, D. D’Amato, H. Mäkinen, M. L. Paracchini, C. Liquete, B. Egoh, D. Geneletti, and N. D. Crossman, Ecol. Indic. 74, 392 (2017)

[15] P. E. Purwanto AD, Asriningrum W., Winarso G., in Di Hear. Semin. Nas. Penginderaan Jauh, Kartasasmita et al (ed)(Bogor, Indonesia, 21 April 2014)

[16] C. Reichel, U. U. Frömming, and M. Glaser, Reg. Environ. Chang. 9, 335 (2009)

[17] A. I. Robertson and N. C. Duke, Mar. Biol. 96, 193 (1987) 
[18] H. Ruitenbeek, Mangrove Management: An Economic Analysis of Management Options with a Focus on Bintuni Bay, Irian Jaya (EMDI/KLH, Jakarta, 1992)

[19] L. K. Sari, L. Adrianto, K. Soewardi, Atmadipoera, A. S., and E. Hilmi, in AIP Conf. Proc. (AIP Publishing, n.d.), p. Vol. 1730, No. 1, 080002

[20] Sasaki Y., Sunarto H., hutan Mangrove. Segara Anakan Lagoon. Dalam: Takashima F, Soewardi K, Editor. Penilaian ekologi Untuk Perencanaan Pengelolaan Segara Anakan Lagoon, Cilacap, Jawa Tengah. NODAI Pusat Program Internasional. Tokyo University of Agriculture. JSPS-DGHE Program, pp. 95-106 (1994)

[21] S. Sukardjo, Malaysian J. Sci. 35, 73 (2016)

[22] B. P. Statistik, Kecamatan Kampung Laut Dalam Angka Tahun 2017 (Badan Pusat Statistik, Cilacap, 2017)

[23] C. Kusmana, in Pros. Semin. Nas. Masy Biodivers. Indones. Vol. 1 Nomor 8 Hal 1747 (2015)

[24] L. HF, Ulasan Sastra, Pemantauan Lingkungan Segara Anakan Dan Penggunaan Proyek Yang Optimal (Institut Teknik Hidrolik, Badan Penelitian dan Pengembangan, Departemen Pekerjaan Umum, Indonesia, 1984)

[25] M. E. Assessment, Ecosystem And Human Well-Bein: Current State and Trends (Islandpres, Wasington, 2005)

[26] W. B. Setyawan, in Semin. Nas. (Biodiversitas Dan Bioteknol. Sumberd. Akuatik) (2010)

[27] E. Yuwono, T. Jennerjahn, I. Nordhaus, E. Riyanto, M. Sastranegara, and R. Pribadi, Asian J. Water, Environ. Pollut. 4, 61 (2007) 